\title{
Pemanfaatan sampah styrofoam untuk pembuatan lem lateks dalam upaya mengurangi limbah styrofoam di TPA Muara Fajar Timur Kecamatan Rumbai Pekanbaru
}

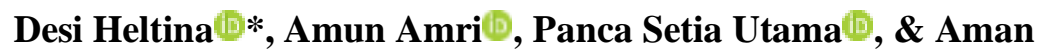 \\ Universitas Riau \\ *desi.heltina@lecturer.unri.ac.id
}

\begin{abstract}
Abstrak. Berbagai jenis sampah terdapat di TPA Muara Fajar Timur, Kecamatan Rumbai Pekanbaru. Salah satu sampah yang tidak terurai adalah styrofoam. Sampah styrofoam jika tidak ditangani secara serius maka akan berdampak pada lingkungan dan membahayakan masyarakat di sekitarnya. Sampah styrofoam ini mempunyai senyawa polisterena foam yang mengandung bahan berbahaya bagi kesehatan dan lingkungan. Untuk itu perlu diupayakan penanganan limbah styrofoam tersebut yaitu dengan mendaur ulang styrofoam menjadi produk-produk yang berguna dan bernilai ekonomis. Salah satu pemanfaatan limbah styrofoam adalah membuat lem lateks. Lem lateks merupakan produk yang banyak digunakan oleh masyarakat sehingga jika diproduksi akan dapat memenuhi kebutuhan baik untuk sendiri maupun untuk kebutuhan masyarakat. Lem lateks dibuat dari styrofoam dengan cara menambahkan toluene dan surfaktan (sodium lauryl sulfat /SLS) atau dengan penambahan bensin pada stryrofoam. Hasil yang diperoleh adalah kegiatan ini adalah masyarakat dapat memahami dan dapat mampu membuat lem lateks. Dari hasil kuisioner keberhasilan menunjukkan tingginya minat dan manfaat kegiatan ini. Hal ini menunjukkan bahwa kegiatan ini telah berhasil dilaksanakan di kelurahan Muara Fajar Timur Kecamatan Rumbai Pekanbaru.
\end{abstract}

Kata kunci: stryrofoam, lem lateks, toluene, bensin, wirausaha

\begin{abstract}
Various types of waste are found in TPA Muara Fajar Timur, Rumbai District, Pekanbaru. One of the waste that does not decompose is styrofoam. If styrofoam is not handled seriously, it will have an impact on the environment and endanger the surrounding community. Styrofoam waste contains polystyrene foam which contains hazardous materials for health and the environment. For this reason, efforts should be made to handle the styrofoam waste, namely by recycling styrofoam into useful and economical products. One of the uses of Styrofoam waste is making latex glue. Latex glue is a product that is widely used by the community so that if it is produced it will be able to meet the needs both for themselves and for the needs of the community. Latex glue is made from styrofoam by adding toluene and surfactants (sodium lauryl sulfate / SLS) or by adding gasoline to Styrofoam. The results obtained were that the community could understand and be able to make latex glue. The results of the success questionnaire show the high interest and benefits of this activity. This shows that this activity has been successfully implemented in Muara Fajar Timur Village, Rumbai District, Pekanbaru.
\end{abstract}

Keywords: styrofoam, latex glue, toluene, gasoline, entrepreneurship

To cite this article: Heltina, D., A. Amri., P. S. Utama., \& Aman. 2020. Pemanfaatan sampah styrofoam untuk pembuatan lem lateks dalam upaya mengurangi limbah styrofoam di TPA Muara Fajar Timur Kecamatan Rumbai Pekanbaru. Unri Conference Series: Community Engagement 2: 72-76. https://doi.org/10.31258/unricsce.2.72-76

(C) 2020 Authors

Peer-review under responsibility of the organizing committee of Seminar Nasional Pemberdayaan Masyarakat 2020 


\section{PENDAHULUAN}

Styrofoam menjadi bahan pilihan populer yang dapat diandalkan bagi para pemilik gerai makanan dan minuman. Styrofoam biasanya digunakan untuk pembungkus makanan karena memiliki keuntungan bagi para penjualnya seperti murah, praktis dan tidak mudah bocor. Bahan dasar yang digunakan dalam pembuatan styrofoam ini terdiri dari 90-95\% polystyrene dan 5-10\% gas n-butana (Maryani dkk, 2018). Styrofoam atau plastik busa masih tergolong salah satu jenis plastik. Hal ini menyebabkan styrofoam tembus cahaya, bersifat kaku dan sangat ringan serta murah tetapi cepat rapuh sehingga dalam proses pembuatannya menggunakan butadien dan seng (Afifah dan Ervin, 2013), sehingga menyebabkan polisterin akan berubah dari sifat jernih menjadi berubah warna putih susu. Styrofoam berbahan dasar dari polystyrene yang termasuk bahan polimer sintetis. Polistirena ditemukan sekitar tahun 1930, proses pembuatannya menggunakan polimerasi adisi dengan tekanan menggunakan proses peniupan. Stirena dapat diperoleh dari sumber alam yaitu petroleum. Stirena merupakan cairan yang tidak berwarna menyerupai minyak dengan bau seperti benzena dan memiliki rumus kimia $\mathrm{C} 6 \mathrm{H} 5 \mathrm{CH}=\mathrm{CH} 2$ atau ditulis sebagai $\mathrm{C} 8 \mathrm{H} 8$ (Wirahadi, 2017). Bahan styrofoam ini mempunyai efek yang perlu diwaspadai karena mengandung bahan berbahaya bagi kesehatan dan lingkungan. Residunya mengandung monomer strirena yang bersifat karsinogik dan dapat memicu timbulnya kanker. Styrofoam yang telah digunakan jika tidak diolah akan menumpuk sehingga akan menjadi limbah. Sampah dari styrofoam ini sulit terdegradasi dan terurai karena sampah styrofoam ini termasuk dalam sampah anorganik, hal ini akan berdampak buruk bagi kesehatan manusia serta lingkungan ( Anggraini, dkk. 2012)

Sampah yang dihasilkan dari kegiatan penduduk dengan jumlah penduduk 10.000 jiwa dan timbulan sampah 2.5 liter/orang/hari dengan asumsi tiap tahun mengalami kenaikan 15\% Jumlah sampah domestik yang terangkut ke TPA dalam jangka waktu minimal 2 kali seminggu berkisar 1493 unit rumah tangga atau hanya sekitar 50\% yang tertangani dari jumlah penduduk di Kelurahan Muara Fajar. Limbah styrofoam yang menumpuk di tempat pembuangan akhir (TPA) menjadi masalah yang sangat penting, mengingat styrofoam merupakan salah satu bahan yang sulit terurai oleh bakteri.

Styrofoam yang terbawa ke perairan dapat merusak ekosistem dan biota baik sungai maupun laut. Limbah Styrofoam dapat didaur ulang setelah 65 th sampai 130 tahun lamanya. Semakin bertambahnya penggunaan styrofoam maka bertambah pula limbah yang dihasilkan. Beberapa perusahaan memang mendaur ulang styrofoam, namun yang dilakukan hanya menghancurkan styrofoam bekas, membentuknya menjadi styrofoam baru kembali dan dijual untuk wadah makanan dan minuman. Data EPA (Enviromental Protection Agency) di tahun 1986 menyebutkan, limbah berbahaya yang dihasilkan dari proses pembuatan styrofoam sebagai penghasil limbah berbahaya ke-5 terbesar di dunia, dan menimbulkan bau kurang sedap serta melepaskan 57 zat berbahaya ke udara. Untuk itu perlu diupayakan cara penanganan limbah styrofoam tersebut dengan cara memanfaatkan kembali styrofoam menjadi produk produk yang berguna dan dapat mempunyai nilai ekonomis sehingga dapat menjadi alternatif dalam pengolahan limbah dan produk yang dihasilkan dapat dikomersilkan oleh masyarakat sehingga dapat membantu meningkatkan perekonomian masyarakat.

Styrofoam yang berasal baik dari limbah bekas pembungkus elektonik / barang yang digunakan untuk penahan getaran seperti telivisi, lemari es dan lain-lain atau barang pecah belah seperti gelas, piring, dan lainnya (Munir dan Dzulkiflih. 2015) serta limbah styrofoam dari bekas tempat makanan. Hal ini akan mengakibatkan penumpukan styrofoam, jika terbuang akan menumpuk di tempat pembuangan sampah atau jika dibuang ke perairan akan mengganggu sistem darainase karena akan menyumbat saluran. Untuk itu perlu diupayakan agar limbah styrofoam dapat dimanfaatkan kembali menjadi produk yang bermanfaat.

Salah satu cara untuk menanggulangi limbah styrofoam ini yaitu dengan cara di daur ulang kembali untuk dibuat menjadi Lem lateks. Pengolahan limbah styrofoam menjadi lem lateks ini dapat memanfaatkan limbah styrofoam untuk digunakan kembali menjadi produk yang berguna dan dapat meminimalisir penumpukan limbah Styrofoam. Selain lem lateks, styrofoam juga bisa dimanfaatkan untuk barang kerajinan tangan bernilai seni, seperti vas bunga, bingkai foto, pembuatan batako mortar semen serta banyak lagi yang lainnya. Sehingga jika hal ini diaplikasikan sangat menjanjikan untuk dikomersialkan.

Pembuatan lem lateks dari stryrofoam menggunakan bahan-bahan seperti toluen dan bensin. Bahan-bahan tersebut secara kimia dapat berfungsi sebagai pelarut sehingga bahan stryrofoam dapat berubah wujud menjadi cair. Surfaktan bersifat sebagai detergen yaitu sebagai pembasuh dari turunan minyak bumi dan pendispersi yang paling efisien. Penggunaan surfaktan seperti sls (sodium lauril sulfat) berfungsi sebagai zat pengemulsi (emulgator) dan stabilizer, karena produk lem lateks pekat yang dihasilkan bersifat menggumpal dan tidak stabil. Pemilihan jenis-jenis emulsi yang digunakan tergantung dari zat dan emulgatornya. Emulsi minyak dalam air emulgator yang baik adalah sabun atau logam-logam alkali (Drelich, 2010). 
Secara umum tujuan kegiatan pengabdian kepada masyarakat ini adalah untuk dapat memberikan informasi kepada masyarakat tentang pemanfaatan limbah styrofoam untuk diolah menjadi barang / produk yang berguna bagi masyarakat. Sedangkan tujuan khususnya adalah

a. Memberikan pengetahuan secara praktis tentang cara pembuatan lem lateks

b. Memberikan pengetahuan kepada masyarakat untuk berwirausaha

Melalui kegiatan kepada masyarakat ini, diharapkan dapat memberi nilai tambah berupa ilmu pengetahuan bagaimana cara membuat lem lateks dan produk lainnya sehingga masyarakat dapat membuat lem lateks sendiri dan dapat dijadikan salah satu usaha bisnis sebagai alternatif menambah penghasilan masyarakat serta dapat menambah dan menumbuhkan jiwa kewirausahaan masyarakat.

\section{METODE PENERAPAN}

Pembuatan lem lateks dari stryrofoam ini dilaksanakan di Kelurahan Muara Fajar Timur Kecamatan Rumbai. Kegiatan ini diikuti oleh Bapak-bapak dan Ibu-ibu PKK kelurahan Muara Fajar Timur. Peserta yang telah mengikuti kegiatan ini diharapkan dapat memahami dan mempraktekkan teori pembuatan lem lateks dari styrofoam di lingkungan keluarganya, mampu memproduksi lem lateks sendiri untuk dipasarkan sehingga mampu berwirausaha dan pada akhirnya akan dapat menambah penghasilan masyarakat.

Adapun bahan yang digunakan untuk pembuatan lem lateks dari styrofoam yaitu :

1. Menggunakan toluene ditambah surfaktan sls (sodium lauryl sulfonat)

a. Alat yang Diperlukan : Peralatan yang digunakan adalah gelas beker, gelas ukur, dan batang pengaduk.

b. Bahan yang Diperlukan : Sampah styrofoam dari limbah kemasan makanan, toluen, aquades, surfaktan sls (sodium lauryl sulfate).

c. Prosedur percobaan :

30 g polistirena dimasukkan ke dalam beker gelas, kemudian ditambahkan $70 \mathrm{ml}$ toluena. Kemudian diaduk selama 10 menit dan didiamkan selama 1 hari (Hui Y. H., 1996). Larutan polistirena yang telah menjadi lateks, diambil sebanyak $90 \mathrm{ml}$ dan dimasukkan kedalam gelas beker kemudian ditambahkan $10 \mathrm{ml}$ aquades. Setelah itu tambahkan $10 \mathrm{ml}$ sls (sodium lauryl sulfonat) yaitu dengan melarutkan 0,1 gram dalam $10 \mathrm{ml}$ aquades. Lalu kemudian diaduk selama 10 menit dan didiamkan selama 1 jam (Yeyen dkk, 2018) dan diperoleh lem lateks.

2. Menggunakan Bensin

a. Alat yang Diperlukan

Peralatan yang digunakan adalah gelas beker, gelas ukur, saringan, dan batang pengaduk

b. Bahan yang Diperlukan

Bahan yang digunakan adalah sampah syrofoam dari limbah kemasan makanan, dan bensin.

c. Prosedur Percobaan

Styrofoam dimasukkan ke dalam wadah gelas beker, kemudian disiram dengan bensin sambil diaduk sampai styrofoam menjadi lunak. Campuran bensin dan lem lateks yang lunak lalu dipisahkan dengan saringan sehingga diperoleh lem lateks.

Kegiatan ini dilakukan dalam bentuk penyuluhan dan demo yaitu mengenalkan cara pembuatan lem lateks dari styrofoam dengan metode ceramah, diskusi dan melakukan demonstrasi pembuatan lem lateks dari styrofoam. Materi yang diberikan dalam kegiatan penyuluhan ini adalah adalah :

1. Penyuluhan yaitu pengenalan cara pembuatan lem lateks dari styrofoam

2. Praktek/demontrasi tentang pembuatan lem lateks dari styrofoam

3. Motivasi kepada masyarakat untuk meningkatkan pendapatan keluarga melalui wirausaha kecil-kecilan salah satunya memproduksi lem lateks

4. Setelah demonstrasi atau praktek lapangan, dilakukan evaluasi dan dikusi untuk melihat dampak dari kegiatan ini.

Evaluasi dalam kegiatan ini dilakukan sebelum dan sesudah pelatihan pembuatan lem lateks dari styrofoam.

Evaluasi dilakukan dengan menggunakan kuisioner. Penilaian dikelompokkan dalam tingkatan kurang berminat, biasa- biasa saja, bermaninat/ bermanfaat, dan sangat bermanfaat. 


\section{HASIL DAN KETERCAPAIAN SASARAN}

Pelatihan ipteks tentang pembuatan lem lateks dari styrofoam telah dilaksanakan di kelurahan Muara Fajar Timur Kecamatan Rumbai. Kegiatan ini berlangsung dalam beberapa kali pertemuan dengan pemberian materi dalam bentuk ceramah, diskusi dan praktek langsung dilapangan.

Kegiatan pembuatan lem lateks diikuti dengan serius yang dihadiri oleh peserta yang terdiri dari perangkat kelurahan, kepala Dusun, Bapak-bapak, serta ibu-ibu PKK kelurahan Muara Fajar Timur. Kegiatan Demonstrasi pembuatan lem lateks yang dilakukan peserta sesuai dengan materi yang telah disusun sebelumnya.

Dari kegiatan ini menghasilkan lem lateks yang dapat dipergunakan untuk melengkapi kebutuhan dirumah. Pembuatan lem lateks ini dapat bermanfaat untuk menambah pendapatan rumah tangga karena produksi lem lateks dapat dijual.

Hasil kuisioner yang diperoleh dari para peserta kegiatan yang diberikan setelah pelatihan pembuatan lem lateks dilaksanakan. Hasil kuisioner memberikan informasi bahwa dari jumlah peserta yang hadir diperoleh data yang paham dengan kegiatan pelatihan ini adalah $92 \%$, yang berminat serta sangat berminat mengikuti pelatihan adalah $92 \%$, dan yang menyatakan bahwa kegiatan ini bermanfaat serta sangat bermanfaat adalah $92 \%$

Dari hasil evaluasi berupa data dari kuisioner, tanya jawab dan diskusi dengan para peserta serta dari praktek yang dilakukan dapat diperoleh hasil dari kegiatan penyuluhan dan pembuatan lem lateks sebagai berikut :

1. Peserta belum pernah mengikuti kegiatan penyuluhan dan pembuatan lem lateks dari styrofoam.

2. Peserta sangat berminat mengikuti kegiatan ini.

3. Peserta memahami materi yang disampaikan dalam kegiatan ini.

4. Kegiatan ini sangat bermaafaat bagi peserta.

5. Kegiatan ini sangat menarik perhatian bagi peserta.

6. Tingginya nilai kepuasan yang diberikan terhadap kegiatan ini dalam skala 1- 5 memberikan nilai paling banyak 5 (baik sekali).

Berhasilnya kegiatan ini didukung oleh:

1. Para peserta pelatihan memiliki pendidikan SMP dan sarjana

2. Para peserta memiliki motivasi yang tinggi terhadap kegiatan ini

3. Kegiatan ini sangat didukung oleh pihak pemerintah khususnya kelurahan Muara Fajar Timur

Berdasarkan hasil di atas, pelaksanaan kegiatan pemanfaatan sampah styrofoam menjadi lem lateks di kelurahan Muara Fajar Timur kecamatan Rumbai Pekanbaru telah berhasil dilaksanakan dan sesuai dengan yang direncanakan.

\section{KESIMPULAN}

Hasil kegiatan dari pemanfaatan limbah styrofoam untuk membuat lem lateks dapat disimpulkan sebagai berikut; Kegiatan pemanfaatan limbah styrofoam menjadi lem lateks di Kelurahan Muara Fajar Timur Kecamatan Rumbai Kota Pekanbaru telah berhasil dilaksanakan, Peserta yang mengikuti kegiatan ini telah dapat memahami cara pembuatan lem lateks, Kegiatan ini sangat bermanfaat bagi masyarakat Kelurahan Muara Fajar Timur, Kegiatan ini dapat meningkatkan pengetahuan dan teknologi bagi masyarakat tentang cara pembuatan lem lateks dan memberikan pengetahuan dalam berwirausaha.

\section{UCAPAN TERIMA KASIH}

Ucapan terima kasih penulis sampaikan kepada Ketua Lembaga Penelitian dan Pengabdian Masyarakat Universitas Riau yang telah mendukung serta memberikan bantuan dana dalam kegiatan pengabdian ini.

\section{DAFTAR PUSTAKA}

Afifah, Ervin. 2013. Bahaya Styrofoam terhadap Kesehatan dan Lingkungan. Skripsi sarjana strata 1 Program Studi Biologi Bandung: Universitas Pendidikan Indonesia.

Anggraini, I.D., Wustoni, S., Ayurini, M. 2012. Lembaran Kemasan Makanan Alami dari Limbah Kulit Jeruk. Program Kreativitas Mahasiswa Artikel Ilmiah. Bandung: Institut Teknologi Bandung. 
Drelich. A., Gomez, F., dan Clausse, D. 2010. Evolution of water-in-oil emulsions stabilized with solid particles influence of add emulsifier. Journal of Colloids and surface A: Physicochemical and Engineering Aspect, 365 (2010), 171-177.

Maryani, Y., Kanani, N., Rusdi . 2008. Pembuatan Lem Lateks Dari Limbah Styrofoam Yang Digunakan Untuk Kemasan Makanan. Jurnal TEKNIKA, 12(2).

Munir, M. and Dzulkiflih. 2015. Pemanfaatan Flux pada Styrofoam sebagai Bahan Dasar Peredam Suara dengan Metode Tabung Impedansi. Jurnal Inovasi Fisika Indonesia, 4(3), 41-47.

Wirahadi, Michelli. 2017. Elemen Interior Berbahan Baku Pengolahan Sampah Styrofoam dan Sampah Kulit Jeruk. JURNAL INTRA, 5(2), 144-153.

Hui YH, 1996, Bailey's Industri Oil and Fat Products, Edisi ke-5, Volume ke-2. New York: John Willey and Sons. Inc. Dipenogoro. Semarang.

Physicochemical and Engineering Aspect, 365(2010), 171-177.

https://www.itera.ac.id/penelitian-dosen-itera-tentangpemanfaatan- limbah-styrofoam-masuk-peringkattertinggi- jurnalinternasional/

https://www.youtube.com/watch?v=0NzIxLrhdFY 